\title{
Synthesis of a p38 Kinase Inhibitor
}<smiles>CCOC(=O)CN/C=C(/C(=O)OCC)C(=O)OCCNC(=O)C(=CNC)C(=O)OCC</smiles>

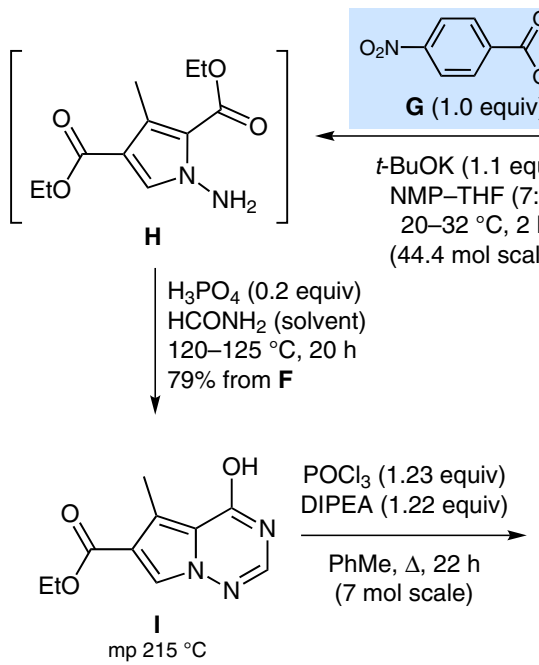<smiles>CCOC(=O)c1c[nH]c(C(=O)OCC)c1C</smiles><smiles>[X][M]OC(=O)c1cn2ncnc(Nc3cc(C(=O)OC)ccc3C)c2c1C</smiles><smiles>CCNC(=O)c1cn2ncnc(Nc3cc(C(=O)NOC)ccc3C)c2c1C</smiles>

EDAC. $\mathrm{HCl}, \mathrm{HOBt}$ aq $\mathrm{EtNH}_{2}$ (70 wt\%) DMF, $30-35^{\circ} \mathrm{C}, 1 \mathrm{~h}$
$88 \%(4.7 \mathrm{~mol}$ scale $)$

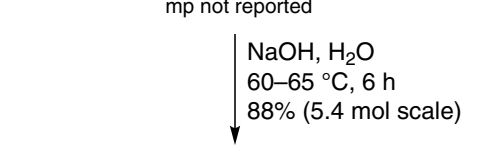
$88 \%(4.7 \mathrm{~mol}$ scale $)$<smiles>CONC(=O)c1ccc(C)c(Nc2ncnn3cc(C(=O)O)c(C)c23)c1</smiles>

Significance: The target pyrrolotriazine is a p38 kinase inhibitor that was a lead compound for the treatment of rheumatoid arthritis. The synthesis depicted features a safe and scalable $\mathrm{N}$-amination of the pyrrole $\mathbf{F}$ using $\mathrm{O}$-(4-nitrobenzoyl)hydroxylamine $(\mathbf{G})$. The synthesis delivered $1.6 \mathrm{~kg}$ of active pharmaceutical ingredient (API) in $26 \%$ overall yield.
Comment: Competing ester hydrolysis products generated in the condensation of $\mathbf{E}$ to the pyrrole $\mathbf{F}$ were minimized by adding ethyl trifluoroacetate as a water scavenger. A large-scale process for the synthesis of the crystalline O-4-(nitrobenzoyl)hydroxylamine $(\mathbf{G})$ is described.

SYNFACTS Contributors: Philip Kocienski 